\title{
MULTIFACTORIAL MODEL OF ATTITUDES TOWARDS APPEARANCE: EMPIRICAL INVESTIGATIONS ${ }^{1}$
}

\begin{abstract}
This study is focusing on interrelations between attitudes towards Appearance (AP), value functional significance of AP, and life satisfaction. The study is aimed at gaining a theoretical foundation of the developed Multifactorial Model of Attitudes towards AP as well as at empirical testing of the interrelations between the single factors of the model and their combined influence on life satisfaction. It is hypothesised that a different combination of the single factors of the Multifactorial Model of Attitudes towards AP has a different impact on life satisfaction. The participants were 86 females and 86 males aged between 17 and 25 years. The inventory "Diagnostics of Real Structure of Personality Value Orientations" (Bubnova, 1999) the questionnaires "Significance of AP in Various Life Situations" (Labunskaya \& Serikov, 2018), Attitudes towards AP, Satisfaction and Concern" (Labunskaya $\&$ Kapitanova, 2016), the AP Perfectionism Scale (APPS) (Srivastava, 2009) and the Life Satisfaction Index developed by Neugarten and adopted by N. V. Panina (1993) were administered. The factorial analysis revealed two types of interrelations that relate to different components of the developed Multifactorial Model of Attitudes towards AP. The results showed that considering AP as a value, attributing of higher significance to AP in various interaction contexts as well as higher AP perfectionism lead to lower life satisfaction.
\end{abstract}

Keywords: multifactorial model, life spheres, value of AP, significance of AP, attitude toward AP, life satisfaction.

Introduction

The theoretical foundation of the developed Multifactorial Model of Attitudes towards AP. This investigation is focusing on the interrelations of attitudes towards AP, values, functional significance of AP and life satisfaction as a cen-

\footnotetext{
This work was supported by the Russian Scientific Foundation (project № 171801260) “The social psychology of appearance: functions, significance, satisfaction, concerns, the interpretation in the interpersonal and intragroup interaction in youth environment".
}

tral issue of the psychological research in the field of AP investigation. The new perspective on this issue is grounded in the proposed Multifactorial Model of Attitudes towards AP (Labunskaya $\&$ Serikov, 2018). The analysis of the previous research relating to the impact of social perception, estimation and self-estimation, AP interpretation, attitudes, self-concepts and experience on AP (Labunskaya \& Kapitanova, 2016; Labunskay \& Drozdova, 2017) demonstrated following tendencies in theoretical concepts. First, the one, two or three factors approach to 
the investigation of phenomena relating to AP is dominating in modern research (Grabe, Monique, \& Shibley, 2008; Webb \& Zimmer-Gembeck, 2016; Webb \& Zimmer-Gembeck, 2014).

Second, while studying such phenomena as value of AP, investment power of AP, sensitivity towards and significance of AP authors link them very often to concern and satisfaction with AP as well as to self-estimation of AP (Chang, Jarry, \& Kong, 2014; Swami \& Furnham, 2009; Trekels \& Eggermont, 2017 ${ }^{\mathrm{a}}$; Trekels \& Eggermont, 2017 ${ }^{\mathrm{b}}$ ). Taking into account, the affective components of AP researchers underline the role of feedback of others on AP (Carriere \& Kluck, 2014; Dian \& Kühne, 2015; Goldsmith \& Byers, 2016) and the influence of comments of others concerning AP of other people (Carriere \& Kluck, 2014; Herbozo \& Thompson, 2006). For instance in the study of Carriere \& Kluck (2014) was stated that there are significant positive correlations between negative comments and body satisfaction as well as between positive feedback on AP, such as weight, and relationships satisfaction. Thus, the concentration on different aspects of AP, "objectification" of AP, also through feedback and estimation of AP through others, diminish the satisfaction with AP and increase the shame attitude towards AP (Noser \& Zeigler-Hill, 2014). Uncomfortable feelings associated with AP, concern with AP, anxiety and dissatisfaction with AP are mainly considered as coursed by the interplay of macro and micro factors, especially, by such demographic factors as gender, age, education, economic status etc. (Castonguay, Sabiston, Crocker, \& Mack, 2014).
Third, the well-known statement postulated by Schwartz (Schwartz, 2012) that values are dependent variables could be applied to the value of AP. One of our previous researches (Labunskaya \& Serikov, 2018; Labunskaya, $2018^{\mathrm{b}}$ ) showed that similar to the value of love value of AP in youth takes a middle position in the hierarchy of value orientations. Correlation analysis testified a significant association between the value of AP and such values as the achievement of high social status, power, acceptance and respect from others, social influence, communication.

Fourth, authors pointed out that functional significance of AP varies as a factor of life circumstances: communication and friendship, carrier and job, academic performance, family and romantic relationships (Serikov, 2018; Labunskaya, 2019). The results of one of our previous studies demonstrated that agreement with statements about attractive AP varies dependent on the actual life situation (Labunskaya, 2018 ${ }^{\mathrm{a}}$ ). Youth participants reported the more critical role of attractive AP in the spheres of friendship and communication and for the feeling of happiness compared to academic performance, carrier, romantic relationships or change of lifestyle. Further on, youth participants perceived an attractive AP as connected to happiness, to better chances of finding a partner and to better chances in the spheres of friendship and romantic relationships. Attractive students are expected to be more confident in communicating with lecturers and peers, with higher chances of finding good friends, of finding perfect partner, to build a family and to be accessible within the peer group. In sum, the received results testified that youth people 
perceive AP as social and humanitarian capital.

Fifth, the explanation of the functional significance of AP and its influence on individual's everyday life based on the concept of value of AP which defines AP as responsible for everything that happens to an individual and as a type of "investment" in individual's well-being and not-well-being (Chang, Jarry, \& Kong, 2014; Moss, Lawson, \& White, 2014). In the opinion of the Gupta, Etcoff \& Jaeger (2016) the intensity of interrelations between AP and well-being/not-well-being depends on demographic variables and intellectual abilities. The authors pointed out that the attractiveness of AP has a direct impact on individual's states and in this way influences another life parameter such as the feeling of happiness (Trekels \& Eggermont 2017; Trekels \& Eggermont, 2017; Kaczmarek, Enko, Awdziejczyk, \& Hoffmann, 2016; Shinners, 2009). The intensity of AP influence depends on concentration on different AP components that strengthen the desire to look better in order to live better and be happier.

Sixth, expectations that attractive AP can increase life quality, can help to become a better job, look smarter, be happier and more confident are characteristic for different social groups (Shinners, 2009; Anderson, John, Keltner, \& Kring, 2001; Beall \& Can, 2007; Johnson, Podratz, Dipboye, \& Gibbons, 2010). Connected to this phenomenon the modern social psychology raises the question about the privileges of people with attractive AP (Dotse \& Asumeng, 2015; Kanazawa, 2011; Toosi, 2016; Ramsey \& Harcourt, 2009). Following this claim, Carr, T., Harris, D., \& James (2000), underlined the vital role of AP in increasing life quality and welfare.

Basing on listed above theoretical concepts and empirical evidence, the Multifactorial Model of Attitudes towards AP was developed. The value of AP and related to its functional significance of AP is placed into the centre of the model. Demographic factors and an individual's spheres of life are included in the model as determinant factors. The interplay of these factors influences not only the value of AP but also determine the attitude towards AP which contains self-estimations of AP, concern and satisfaction with AP, and AP perfectionism. The interrelations between listed above factors, attitudes towards AP, its value and functional significance determine in their turn life satisfaction, well-being, and level of social adaptation. The described interrelations influence the development of lookism and lookphobia relating to psychological and social-psychological difficulties in the spheres of business, interpersonal and intergroup communication (Figure 1).

\section{Aim and Hypotheses of the Study}

This study is aimed at empirical testing of the interrelations between factors described in the developed Multifactorial Model of Attitudes towards AP and at the defining of those factors that influence life satisfaction. Taking into account the peculiarities of the phenomena linked to AP as well as the results of our previous research we hypothesise that different combination of the single factors of the Multifactorial Model of Attitudes towards AP has a different impact on life satisfaction. 
Multifactorial Model of Attitudes towards AP

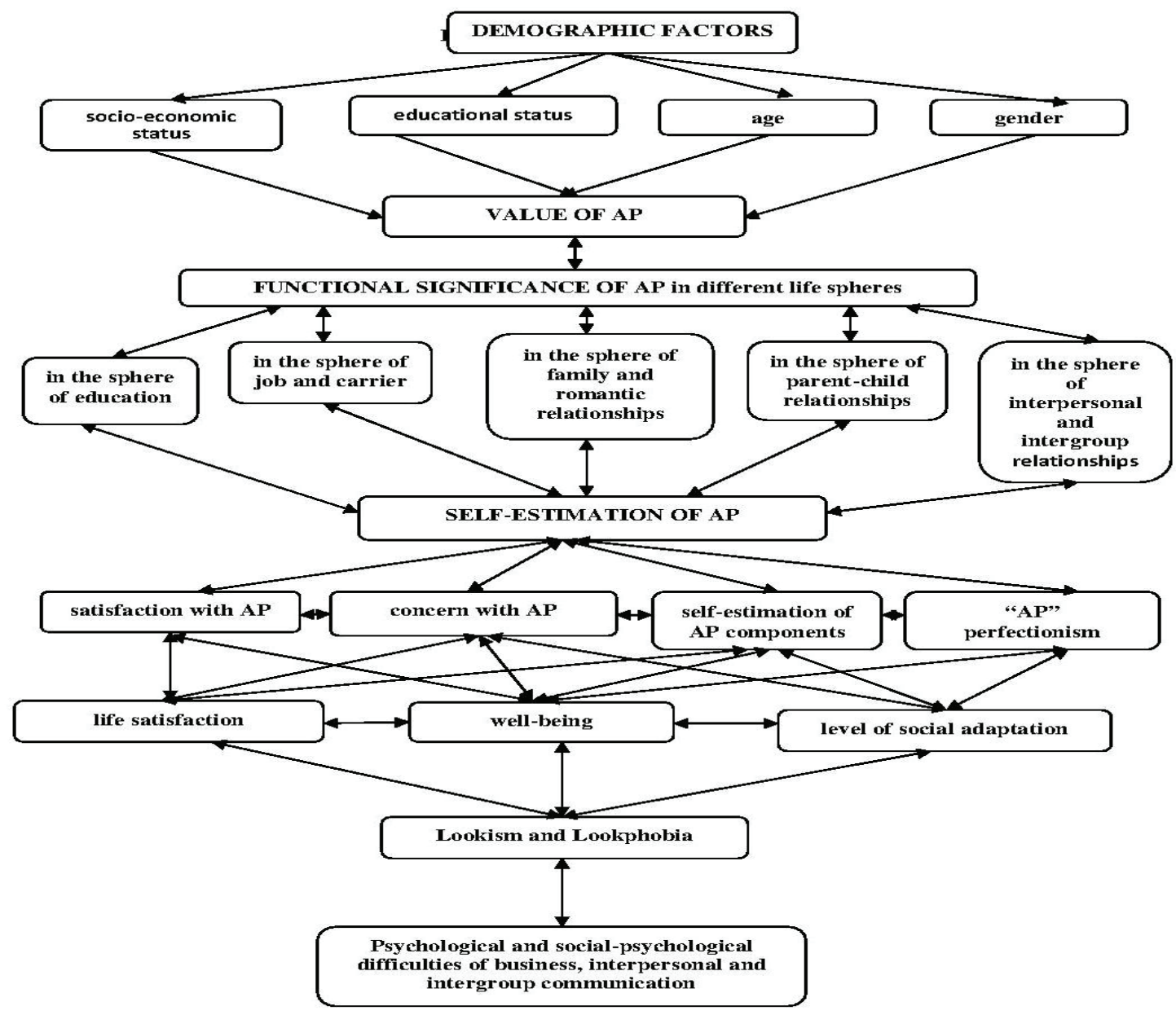

Participants and Methods

The participants were 86 females and 86 males aged between 17 and 25 years $(M=20.07$, SD: 2.23). The modified version of the inventory "Diagnostics of Real Structure of Personality Value Orientations" developed by Bubnova S. S. (1999) was administered to register the value of AP. The modification of the inventory covered the reformulation of items describing 11 types of value orientations for the context of AP: 1) "Is improvement of AP (taking care, correction, creation) an important part of individual's life?"; 2) "Is it crucial to have attractive, beautiful AP?";
3) "Can AP play an important role in your life?"; 4) "Could you tell that you are depressed because of estimation of your AP through others?"; 5) "Would you like others to be impressed by your AP?"; 6) "Does the AP of others impact your attitudes towards them?". The combination of these statements was related to 11 types of value of AP. The scores were calculated as a sum of "yes" and "no" answers.

The questionnaire "Significance of AP in Various Interaction Situations" (Labunskaya \& Serikov, 2018) was applied to register the significance of AP in different life situation. This questionnaire includes 12 statements describing dif- 
ferent life spheres: communication and friendship, job and carrier, academic performance, family and romantic relationships. Several items address lifestyle and feeling of happiness. Using a five-point Likert scale with " 5 " absolutely correct and "1" absolutely incorrect participants answered the question "What kind of changes would happen to your self-estimation, relations to others and life perspectives if you would have more attractive AP?" Lower self-reported influence of AP attractiveness on different spheres of life is linked to lower the value of AP. The integral index of the significance of AP is estimated as a sum of scores of the significance of AP for different spheres of life divided by the number of the spheres of life administered in the questionnaire.

Three questionnaires "Content-Evaluative Interpretation of AP” (Labunskaya, 2009). "Attitudes towards AP: Satisfaction and Concern" (Labunskaya \& Kapitanova, 2016), and "AP Perfectionism Scale" (APPS) (Srivastava, 2009) were applied to register the attitudes towards AP. The first includes scales that relate to the selfestimation of different components of AP (face, body, design of AP) and holistic characteristics of AP: the attractiveness of AP for a partner of the opposite gender, femininity/masculinity of AP, and sexuality of AP. Using a ten-point Likert scale participants were asked to estimate the correspondence of various components to their own AP: 1) self-estimation of face; 2) selfestimation of body; 3) self-estimation of AP design; 4) self-estimation of AP attractiveness for a partner of the opposite gender; 5) self-estimation of femininity/masculinity and sexuality of AP. Along with self-estimations of single components of AP, we calculated the integral score of self-estimation of AP as a sum of single scores divided by the number of self-estimations. The second questionnaire "Attitudes towards AP: Satisfaction and Concern" (Labunskaya \& Kapitanova, 2016) includes 12 items. The concern with AP was operationalised as the intensity of feelings of unease, uncomfortable and shame experienced in different interaction situation coursed by AP. Satisfaction with AP was operationalised as the frequency of situations in which participants impressed the others due to their AP, for example, "My relatives perceive me as an attractive person". Participants expressed their agreement with the items on a ten-point Likert scale. The concern and satisfaction indexes were calculated as a sum of scores achieved correspondently at each of the dimension. The third questionnaire "AP Perfectionism Scale" (APPS) developed by Srivastava (2009) contains ten statements relating to AP perfectionism or perfectionistic attitude towards AP that participants had to agree or disagree with using a seven-point Likert scale.

Life satisfaction was measured using the Life Satisfaction Index (LS I) developed by Neugarten and adopted by N. V. Panina (1993). It consists of 20 items grouped in 5 dimensions: life interest, the consequent achievement of life goals (volition, decisiveness, and determination), correspondence between planed and real goal achievement, positive estimation of own characteristics and behaviour, overall mood quality. LSI is an integral phenomenon reflecting an individual's experiences concerning attitudes towards himself and life quality. The maximal score is 40 points: the high score is between 31 and 39; the middle score is between 25 and 30 , the low score is between 24 and 0 . The high score correlates with low emotional tense, high emotional stability, low anxiety, high psychological comfort, high satisfaction with a given situation and own role in it. 
Results

$67.4 \%$ of participants have a low level of LSI, $23.3 \%$ reported a middle level of LSI and only $9.3 \%$ of participants had a high level of LSI $(\mathrm{M}=20.33$, Min=4.0, Max=39.0). Descriptive statistics (Table 1.) showed that most of the participants $(50 \%)$ agree with the high value of AP and its essential role in various life spheres. Selfestimation of the components and holistic characteristics of AP are associated with middle level of satisfaction and concern with AP and perfectionistic attitudes towards AP. At the same time, the analysis of standard deviation revealed a significant variation in attitudes towards AP.

Table 1 .

Descriptive Statistics

\begin{tabular}{|l|r|r|r|r|r|}
\hline Variables & N & Min. & Max. & \multicolumn{1}{c|}{ M } & SD \\
\hline Age & 172 & 17 & 25 & 20,07 & 2,226 \\
\hline Value of AP & 172 &, 0 & 6,0 & 2,767 & 1,6591 \\
\hline Self-estimation of face & 172 & 1,0 & 10,0 & 5,942 & 1,8372 \\
\hline Self-estimation of body & 172 & 1,0 & 10,0 & 5,299 & 2,2067 \\
\hline Self-estimation of AP design & 172 & 1,0 & 10,0 & 6,116 & 1,9250 \\
\hline Self-estimation of AP sexuality & 172 & 1,0 & 10,0 & 4,855 & 2,0191 \\
\hline Self-estimation of AP for a partner of the opposite gender & 172 & 1,0 & 10,0 & 5,381 & 2,1129 \\
\hline Self-estimation of femininity/masculinity of AP & 172 & 1,0 & 10,0 & 6,180 & 2,0699 \\
\hline Integral self-estimation of AP & 172 & 1,0 & 10,0 & 6,081 & 1,5512 \\
\hline Concern with AP & 172 & 2,2 & 9,6 & 5,158 & 1,5826 \\
\hline Satisfaction with AP & 172 & 1,0 & 9,8 & 6,199 & 1,8493 \\
\hline Life Satisfaction Index (LSI) & 172 & 4,0 & 39,0 & 20,337 & 8,1873 \\
\hline Appearance perfectionism & 172 & 1,2 & 7,0 & 3,958 & 1,5669 \\
\hline Integral score of AP significance & 172 & 1,0 & 5,0 & 2,743 & 1,0588 \\
\hline Total N & 172 & & & & \\
\hline
\end{tabular}

The central hypothesis was tested using factor analysis with principal component analysis (SPSS 21 for Windows). The factor analysis (Table 2) revealed two factors. Variance scores allow concluding, that two factors have values higher than one and thus explain the variance significantly. The first factor explains $50.32 \%$ of the variance and the second factor explains $15.68 \%$ of the variance.

Table 2.

Factor analysis. Total Variance Explained

\begin{tabular}{|c|c|c|c|c|c|c|}
\hline \multirow{2}{*}{ Component } & \multicolumn{3}{|c|}{ Initial eigenvalues\% of } & \multicolumn{3}{|c|}{ Extraction Sum of Squared Loadings\% of } \\
\cline { 2 - 7 } & Total & Variance & $\begin{array}{c}\text { Cummulative } \\
\%\end{array}$ & Total & Variance & $\begin{array}{c}\text { Cummulative } \\
\%\end{array}$ \\
\hline 1 & 6,542 & 50,324 & 50,324 & 6,268 & 48,219 & 48,219 \\
\hline 2 & 2,039 & 15,682 & 66,006 & 2,312 & 17,788 & 66,006 \\
\hline 3 &, 955 & 7,344 & 73,350 & & & \\
\hline 4 &, 650 & 4,997 & 78,347 & & & \\
\hline 5 &, 613 & 4,712 & 83,059 & & & \\
\hline 6 &, 585 & 4,502 & 87,561 & & & \\
\hline 7 &, 433 & 3,327 & 90,888 & & & \\
\hline
\end{tabular}




\begin{tabular}{|l|c|c|c|l|l|l|}
\hline 8 &, 356 & 2,739 & 93,627 & & & \\
\hline 9 &, 287 & 2,207 & 95,834 & & & \\
\hline 10 &, 252 & 1,939 & 97,773 & & & \\
\hline 11 &, 204 & 1,566 & 99,339 & & & \\
\hline 12 &, 064 &, 493 & 99,833 & & & \\
\hline 13 &, 022 &, 167 & 100,000 & & & \\
\hline
\end{tabular}

Extraction method: Principal Component Analysis

As factor loadings reflect correlations between variables the factors with the highest loading scores (Table 2 contains factor loadings with $\mathrm{p}=0.05$ and higher) should be considered. In primary cases, the including of a variable into a factor is evident and depends on the strength of a correlation coefficient respectively. At the same time, it is possible to include the same variable into two or more different factors while there are variables that could not be included in any factor.

Table 3 .

Varimax Rotation Matrix ${ }^{\mathrm{a}}$

\begin{tabular}{|l|c|c|}
\hline Variables & \multicolumn{2}{|c|}{ Factor } \\
\cline { 2 - 3 } & 1 & 2 \\
\hline Value of AP & & $\mathbf{8 3 4}$ \\
\hline Self-estimation of face & $\mathbf{, 8 1 0}$ &,- 124 \\
\hline Self-estimation of body & $\mathbf{, 7 9 0}$ & $-\mathbf{2 6 9}$ \\
\hline Self-estimation of AP design & $\mathbf{, 7 3 7}$ &, 107 \\
\hline Self-estimation of AP sexuality & $\mathbf{, 8 5 8}$ & $-\mathbf{2 4 4}$ \\
\hline Self-estimation of AP for a partner of the opposite gender & $\mathbf{9 4 1}$ &,- 130 \\
\hline Self-estimation of femininity/masculinity of AP & $\mathbf{, 8 6 6}$ &,- 079 \\
\hline Integral self-estimation of AP & $\mathbf{9 5 8}$ &,- 095 \\
\hline Concern with AP & $\mathbf{- , 3 4 0}$ & $\mathbf{, 7 0 5}$ \\
\hline Satisfaction with AP & $\mathbf{, 8 6 0}$ &,- 073 \\
\hline Life Satisfaction Index (LSI) & $\mathbf{3 6 8}$ & $\mathbf{- , 3 7 8}$ \\
\hline AP perfectionism & $\mathbf{3 9 2}$ & $\mathbf{, 4 9 3}$ \\
\hline Integral score of AP significance &,- 083 & $\mathbf{, 7 3 3}$ \\
\hline
\end{tabular}

Extraction Method: Principal Axis Factoring; Rotation Method: Varimax with Kaiser Normalisation;

a. Rotation converged in 3 iterations

The first factor (Table 3) includes all selfestimations of AP, satisfaction with $\mathrm{AP}$ and $\mathrm{AP}$ perfectionism. Life satisfaction was also included in this factor with favourable loading as well as concern with AP - with negative loading. According to psychological content, this factor could be named "Attitudes towards AP - life satisfaction". The second factor contains the value of AP, the significance of AP in different life situations, concern with AP and AP perfectionism. Life satisfaction has a negative loading within this factor. As for the psychological con- tent, this factor could be named "Value and significance of AP - life dissatisfaction".

Thus, two types of interrelations between attitudes towards AP, the value of AP, the significance of AP in different life situations, and life satisfaction could be revealed. The first type is more spread one ( $50.32 \%$ of explained variance). This interrelations type demonstrates that life satisfaction is impacted by a complex of interrelated factors: attitudes to AP (self-estimations of different AP components, satisfaction with AP, and AP perfectionism). Life satisfaction is higher 
if satisfaction with AP is high and concern with AP is low. The second type of interrelations is less frequent as the second factor explains only $15.68 \%$ of the variance. This type of interrelations describes that association between the value of AP, the significance of AP in different life situations, concern with AP, and AP perfectionism course lower life satisfaction.

Altogether, higher life satisfaction is observed if higher attitudes towards AP (all components of self-estimation of AP: self-estimation of face, self-estimation of body, self-estimation of AP design, self-estimation of AP sexuality, self-estimation of AP for a partner of the opposite gender, self-estimation of femininity/masculinity of AP) are linked to satisfaction with AP, and AP perfectionism while value of AP, significance of AP in different life situations, and concern with AP are significantly lower. The lower level of life satisfaction is associated with a higher value of AP, the significance of AP in different life situations, concern with AP, and AP perfectionism.

\section{Conclusions and Discussion}

In this study, we developed the Multifactorial Model of Attitudes towards AP as well as revealed and described different types of interrelations between factors constituting this model. The results demonstrated that the value of AP and the significance of AP in different life situations, concern with $\mathrm{AP}$, and AP perfectionism build a complex of interrelated factors that diminish life satisfaction. Life satisfaction increases due to high self-estimation of AP and especially such its components as the attractiveness of AP for a partner of the opposite gender and self-estimation of femininity/masculinity of AP. Basing on the structure of the Multifactorial
Model of Attitudes towards AP it could be concluded that value of AP combined with the significance of AP increase the intensity of concern with AP and AP perfectionism and in this way decrease life satisfaction. Self-estimation components of attitudes towards AP and satisfaction with AP increase life satisfaction if the role of $\mathrm{AP}$ in different life situations is considered as insignificant and AP is not valued high.

Summing up, youth people who consider $\mathrm{AP}$ as a value and attribute higher significance to AP in different life situations, demonstrate perfectionistic attitude towards AP and experience concern with AP report lower life satisfaction. Youth people with high life satisfaction are satisfied with their AP, report higher self-estimations of AP and consider the role of AP in life situations as insignificant and not valuable. The revealed interrelations of factors having a positive and negative impact on life satisfaction testify that attribution of investment power to AP and overestimation of AP function as asocial and humanitarian capital lead to lower life satisfaction.

\section{REFERENCES}

Anderson, C., John, O., Keltner, D., \& Kring, A. (2001). Who Attains Social Status? Effects of Personality and Physical Attractiveness in Social Groups. Journal of Personality and Social Psychology,81(1), 116-132. doi: 10.1037//00223514.81.1.116.

Beall, A. (2007) Can New Smile Make You Look More Intelligent and Successful? Dent Clin North Am. 51 (2), 289-297. doi: 10.1016/j.cden.2007.02.002.

Bubnova, S.S. (1999). Tsennostnye orientatsiilichnosti kak mnogomernaya nelinei- 
naya sistema (Valuable Orientations of the Personality as Multidimensional Nonlinear System, in Russian). Psikhologicheskii hurnal (Psychological Journal), 20(5), 38-44.

Carr, T., Harris, D., \& James, C. (2000).The Derriford AP Scale (DAS-59): A New Scale to Measure Individual Responses to Living with Problems of AP. British Journal of Health Psychology, 5(2), 201-

215.doi: 10.1348/135910700168865.

Carriere, L. J., \& Kluck, A. S. (2014). AP Commentary from Romantic Partners: Evaluation of an Adapted Measure. Body Image.11(2), 137-145. doi: 10.1016/j.bodyim.2013.12.003.

Castonguay, A. L., Sabiston, C. M., Crocker, P. E., \& Mack, D. E. (2014). Development and Validation of the Body and AP Self-Conscious Emotions Scale (BASES). Body Image. 11(2), 126136.doi:

10.1016/j.bodyim.2013.12.006.

Chang, F. M., Jarry, J. L., Kong, M. A. (2014). AP Investment Mediates the Association between Fear of Negative Evaluation and Dietary Restraint. Body Image, 11(1), 72-76.

doi: 10.1016/j.bodyim.2013.11.002.

Dian, A.de V. \& Kühne, R. (2015). Facebook and Self-Perception: Individual Susceptibility to Negative Social Comparison on Facebook. Personality and Individual, Differences. 86 (Nov.), 217-221. doi: 10.1016/j.paid.2015.05.029.

Dotse, J., \& Asumeng, M. (2015). Relationship between Body Image Satisfaction and Psychological Well-Being: The Impact of Africentric Values. Journal of Social
Science Studies, 2(1), 320-342. doi:10.5296/jsss.v2i1.6843.

Goldsmith, K. M., \& Byers, E. S. (2016). Perceived Impact of Body Feedback from Romantic Partners on Young Adults' Body Image and Sexual Well-Being. Body Image, 17(Jun.), 161-170. doi: 10.1016/j.bodyim.2016.03.008.

Grabe, Sh.,Monique, W. L., \& Shibley, H. J. (2008). The Role of the Media in Body Image Concerns Among Women: A Meta-Analysis of Experimental and Correlation Studies. Psychological Bulletin, 134(3), 460-476. doi: 10.1037/0033-2909.134.3.460.

Gupta, N. D., Etcoff, N. L., \& Jaeger, M.M. (2016).Beauty in Mind: The Effects of Physical Attractiveness on Psychological Well-Being and Distress. Journal of Happiness Studies, 17(3), 1313-1325. doi:10.1007/s10902-015-9644-6.

Herbozo, S, \& Thompson, J. K. (2006). Development and Validation of the Verbal Commentary on Physical AP Scale: Considering both Positive and Negative Commentary. Body Image, 3(4), 335344.

doi:10.1016/j.bodyim.2006.10.001.

Johnson, S. K., Podratz, K. E., Dipboye, R. L., \& Gibbons, E. (2010). Attractiveness Biases in Ratings of Employment Suitability: Tracking Down the "Beauty is Beastly" Effect. The Journal of Social Psychology, 150(3), 301-318. doi: 10.1080/00224540903365414.

Kaczmarek, L. D, Enko, J., Awdziejczyk, M., Hoffmann, N., Białobrzeska, N., Mielniczuk, P., \& Dombrowski, S. U. (2016). Would You Be Happier if You Looked Better? A Focusing Illusion/ 
Journal of Happiness Studies, 17(1), 357-365. doi: 10.1007/s10902-014-95 98-0.

Kanazawa, S. (2011). Intelligence and Physical Attractiveness .Journal Intelligence, 39(1), 7-14.

doi: 10.1016/j.intell.2010.11.003.

Labunskaya, V. A. (2009). Ne yazyk tela, a yazyk dushi! Psikhologiya neverbal'nogo vyrazheniya lichnosti (No Body Language, and the Language of the Soul! Psychology of Nonverbal Expressions of Expression of Personality, in Russian). Rostov-on-Don: FeniksPress.

Labunskaya, V. A., \& Kapitanova, E. V. (2016). Obespokoennost' i udovletvorennost' studentov svoim vneshnim oblikom kak prediktory samoocenok ego komponentov $i$ kharakteristik (Concerns and Satisfaction of Students to its AP as Predictors of Self-Evaluations of its Components and Characteristics, in Russian). Rossiiskii Psikhologicheskii Zhurnal (Russian Psychological Journal), 13(1), 167-183. doi: 10.21702/rpj.2016.1.14.

Labunskay, V. A., \& Drozdova, I. I.(2017). Teoretiko-empiricheskii analiz vliyaniya socio-kul'turnykh $i$ social'no-psikhologicheskikh faktorov na otsenki i samootsenki molodykh lyudei vneshnego oblika (A Theoretical and Empirical Analysis of the Influence of socioPsychological Factors on Young People's Assessment and Self-Assessment of AP, in Russian). Rossiiskii psihologicheskii zhurnal (Russian Psychological Journal), 14(2), 202-226.

doi: 10.21702/rpj.2017.2.12.

Labunskaya, V. A. $\left(2018^{\mathrm{a}}\right)$. Dinamika pred stavlenii studentov o funkcional'noi znachimosti privlekatel'nogo vneshnego oblika (Dynamics of Representations of Students about the Functional Importance of Attractive AP, in Russian). Zhurnal Socialnaya dinamika (Journal of Social Dynamics) 11, 1119. doi: 10.25136/2409-7144.2018.11. 27887.

Labunskaya V. A. $\left(2018^{\mathrm{b}}\right)$. «Tsennost' vneshnego oblika»v ierarkhii tsennostnykh orientatsii sovremennoi studencheskoi molodezhi («The Value of $\mathrm{AP}$ » in the Hierarchy of Value Orientations of Modern Young Students, in Russian). In V. V. Znakov, \& A. L. Zhuravlev (Eds.), Psikhologiya cheloveka kak sub"ekta poznaniya, obshcheniya i deyatel'nosti (Human Psychology as a Subject of Cognition, Communication and Activity) (pp.742-748). Moscow: RAS Institute of Psychology Press.

Labunskaya, V. A., \& Serikov, G. V. (2018). Teoreticheskie osnovy $i$ metodicheskie podkhody $k$ izucheniyu fenomena «cennost' vneshnego oblika» (Theoretical Foundations and Methodological Approaches to the Study of the Phenomenon the «Value of AP», in Russian). Zhurnal Sotsial'naia psikhologiia $i$ obshchestvo (Journal of Social Psychology and Society), 9(3), 91-103. doi:10.17759/sps.2018090310.

Labunskaya, V. A. (2019). Metodologicheskie podkhody $k$ izucheniyu roli vneshnego oblika v sfere obrazovaniya, kar"ernykh dostizhenii, romanticheskikh otnoshenii molodykh lyudei, $v$ kontekste detsko-roditel'skikh otnoshenii, gruppovoi dinamiki: kruglyi stol na festival 
nauki yuga rossii (Methodological Approaches to Studying of the Role of AP in Different Areas of Joint Life Activity: the Round Table at the Festival of Science of the South of Russia, in Russian). Nauchnyi e-Zhurnal «Institut psihologii Rossiiskoi akademii nauk. Social'naya i ekonomicheskaya psihologiya» (Scientific e-JOURNAL "Institute of Psychology Russian Academy of Sciences. Social and Economic Psychology"), 4(1), 13, 223-245.

Moss, T. P, Lawson, V., \& White, P. (2014). Salience and Valence of AP in a Population with a Visible Difference of AP: Direct and Moderated Relationships with Self-Consciousness, Anxiety and Depression. Public Library of Science One, 9(2). doi: 10.1371/journal.pone.0088435.

Noser, A., \& Zeigler-Hill, V. (2014). Investing in the Ideal: Does Objectified Body Consciousness Mediate the Association between AP Contingent Self-Worth and AP Self-Esteem in Women? Body Image, 11(2), 119-125. doi: 10.1016/j.bodyim.2013.11.006.

Panina, N. V. (1993). Indeks zhiznennoj udovletvorennosti. In M. Kronik (Ed.), Life Line i drugie novye metody psihologii zhiznennogo puti (The Life Satisfaction Index Satisfaction with Life Index. In M. Kronik (Ed.), Life Line and other New Methods of Psychology of Life, in Russian) (pp. 107-114). Moscow: Progress Press.

Ramsey, N., \& Harcourt, D. (Eds.). (2009). Psihologiya vneshnego oblika (The Psychology of AP, in Russian). St. Petersburg: Piter Press.
Schwartz, S. H. (2012). An Overview of the Schwartz Theory of Basic Values. Online Readings in Psychology and Culture. 2(1), from: https://doi.org/10. 9707/2307-0919.1116.

Shinners, E. (2009). Effects of the "What is Beautiful is Good" Stereotype on Perceived Trustworthiness. UW-L J. of Undergraduate Research XII(12), 1-5. Retrieved April 20, 2018 from: https://www.uwlax.edu/urc/juronline/pdf/2009/shinners-erinpsy.pdf.

Srivastava, K. (2009). Conceptualisation and Development of the AP Perfectionism Scale: Preliminary Evidence for Validity and Utility in a College Student Population: Thesis of BS in Psychology. In the University of Michigan. Retrieved February10, 2017 from: http://citeseerx. ist.psu.edu/viewdoc/download?doi=10. 1.1.613.6013\&rep=rep1\&type $=p d f$.

Swami, V., \& Furnham, A. (2009). Psikhologiya krasoty i privlekatel'nosti(The Psychology of Physical Attraction, in Russian). St. Petersburg: Piter Press.

Toosi, M. (2016). Self-Evaluative Salience and Motivational Salience as Predictors of Depressive Affect and AP Based Rejection Sensitivity: Walden Dissertations and Doctoral Studies Collection. Retrieved April 15, 2018 from: https://scholarworks.waldenu.edu/cgi/vi ewcontent.cgi?article $=3489 \&$ context $=$ dissertations.

Trekels, J., \& Eggermont, S. $\left(2017^{\mathrm{b}}\right)$. Linking Magazine Exposure to Social AP Anxiety: The Role of AP Norms in Early Adolescence. Journal of Research on Adolescence, 27(4), 736-751. doi: 10.1111/jora. 12311 . 
Trekels, J., \& Eggermont, S. $\left(2017^{\mathrm{a}}\right)$. Beauty is Good: The AP Culture, the Internalisation of AP Ideals, and Dysfunctional AP Beliefs Among Tweens. Human Communication Research, 43(2), 173192. doi: 10.1111/hcre.12100.

Webb, H. J., \& Zimmer-Gembeck, M. J. (2014). The Role of Friends and Peers in Adolescent Body Dissatisfaction: A Review and Critique of 15 Years of Research.
Journal of Research on Adolescence, 24(4), 564-590.

doi: 10.1111/jora.12084.

Webb, H. J., \& Zimmer-Gembeck, M. J. (2016). A Longitudinal Study of AP-based Rejection Sensitivity and the Peer AP Culture. Journal of Applied Developmental Psychology, 3, 91-100. doi:10.1016/j.appdev.2016.01.004. 